\title{
Studies on the effect of phyllanthus emblica extract on the growth of urinary type struvite crystals invitro
}

\author{
B. Bindhu ${ }^{1 *}$ (D, A. S. Swetha ${ }^{1}$ and K. Veluraja ${ }^{2}$
}

\begin{abstract}
Background: Struvite also called as infection stones occur in the urinary system of humans particularly the women community. The present work was aimed to grow struvite crystals in-vitro using single diffusion gel growth technique and to understand the effect of phyllanthus emblica on its growth.

Methods: Sodium metasilicate gel of density $1.03 \mathrm{~g} / \mathrm{cc}$ was used as the medium for growing the struvite crystals; The phyllanthus emblica extract of $5 \% \mathrm{M} / \mathrm{N}$ concentration was used to understand its effect on struvite crystal crystal nucleation and growth. The well grown crystal samples were characterized by powder XRD, FTIR, UV-vis, Microhardness, SEM and Thermal analysis.
\end{abstract}

Results: The grown struvite crystals had dendritic morphology in both the control and phyllanthus emblica extract added systems. However, it was observed that the nucleation was controlled in the phyllanthus emblica added system when compared to the control system.

Conclusions: The result showed that phyllanthus emblica reduces nucleation of struvite crystals.

Keywords: Struvite; Crystallization; Nucleation; Phyllanthus emblica

\section{Background}

Struvite ( magnesium ammonium phosphate: $\mathrm{MgNH}_{4} \mathrm{PO}_{4}$. $6 \mathrm{H}_{2} \mathrm{O}$ ) is a complex mineral known to assume a number of natural morphological forms including coffin, wedge, short prismatic or short tabular forms [1]. Struvite, accounts for $10-20 \%$ of all renal calculi [2], and is one the major component of urinary stones. These stones can grow rapidly forming "staghorn-calculi", which is a more painful urological disorder [3] threatening human life particularly the women. Priestly and Dunn [4] reported that these stones have a significant chance of causing death in affected patients. They are thought to be associated with urinary tract infections caused by 'urease' secreting bacteria [5, 6]. More recently struvite stones have been shown to be a mixture of struvite and carbonate apatite [7]. Struvite staghorn calculi can form a real threat to the kidney and hence their presence is an indication for active treatment in most individuals [8].

\footnotetext{
* Correspondence: bindhu.krishna80@gmail.com

'Department of Physics, Noorul Islam Centre for Higher Education, Kumaracoil, Tamil Nadu 629180, India

Full list of author information is available at the end of the article
}

Stones that led to kidney loss were frequently struvite stones or stones producing a large mass effect in the kidney [9]. Hence it is vital to study the growth control of struvite crystals. In the present investigation, struvite crystals are grown in vitro using single diffusion gel technique and the growth of these crystals in the presence of phyllanthus emblica fruit extract is investigated.

Traditional system of treating ailments of urinary stone problem using herbal medicines contributes to good health and some of them have been experimentally evaluated [10-15]. Phyllanthus emblica is used in traditional system for the treatment of a broad spectrum of disorders. Phyllanthus emblica is commonly known as Amla and is widely distributed in most tropical and subtropical regions. The extracts or active components of phyllanthus emblica are known to possess several pharmacological effects mainly as antidiabetic, antioxidant, immune modulatory, chemoprotective, hypolipidemic and antiHIV-1 $[16,17]$. Keeping in view the importance of the fruit of phyllanthus emblica, the present work was 
aimed to study its influence on the growth of struvite crystals in vitro.

\section{Methods}

\section{Materials used}

All the chemicals and acids used in the present study are of AR grade. The phyllanthus emblica was thoroughly washed in pipe water and then with distilled water, sliced and dried in shade and was powdered using a grinder. This crude extract was used to perform the experiment. The phyllanthus emblica used in the present study was obtained from the vellimalai hills of southern part of Tamil Nadu. This fruit is harvested twice in a year.

\section{Phyllanthus emblica extract preparation}

The powdered phyllanthus emblica was dissolved in aqueous solution in the ratio 1:5 by weight. This mixture was heated to a temperature of $50{ }^{\circ} \mathrm{C}$ and stirred for about $1 \mathrm{~h}$ using a magnetic stirrer as to obtain a concentrated extract. This solution was then filtered using whatmann filter paper to remove the undissolved component. The resulting solution was used as the extract. This extract was stored in a freezer to avoid microbial contamination.

\section{Experimental procedure}

Sodium metasilicate of known mass was dissolved in distilled water using magnetic stirrer for about $1 \mathrm{~h}$. This solution was then filtered using whattmann filter paper to remove the micro impurities if any and stored in a clean jar for further use.

In the present work, gel of density $1.03 \mathrm{~g} / \mathrm{cc}$ was used for growing the struvite crystals. An aqueous solution of 1.0 M concentration of ammonium dihydrogen phosphate was mixed so that the $\mathrm{pH}$ value 6.0 could be set for the mixture. Utmost care was taken while mixing the solution so that no air bubbles are formed. $25 \mathrm{ml}$ of this solution was then transferred to the crystallization vessels namely test tubes of length $140 \mathrm{~mm}$ and diameter $25 \mathrm{~mm}$ respectively for proper gel setting. After $24 \mathrm{~h}$ of gel setting, $10 \mathrm{ml}$ of magnesium acetate solution of $1.0 \mathrm{M}$ concentration was gently poured over the set gel along the sides of the test tube without disturbing the gel surface. The experiment was carried out at room temperature. Within 5 to $6 \mathrm{~h}$, small crystals of struvite appeared. The growth was completed within a period of 20 days. The grown crystal was collected on the 25th day. These crystals were carefully collected in a clean petri dish and then harvested by removing the gel using distilled water.

To study the effect of phyllanthus emblica extract on the growth of struvite crystals, the following method was adopted. The prepared extract $(4 \mathrm{ml})$ was separately added along with $10 \mathrm{ml}$ of the supernatant solution namely $1.0 \mathrm{M}$ of magnesium acetate and then transferred over the set gel in seven crystallization vessels in order to monitor its effect on the crystal growth in all the vessels. The above procedure was carried out simultaneously with the control system to compare the growth and morphology of struvite crystal grown in the control system and in the presence of phyllanthus emblica extract. The amount of extract solution added is $4 \mathrm{ml}$ which is very little compared to gel ie, the mass ratio of extract to gel $<<1$ and hence the addition of extract will not change the $\mathrm{pH}$ of the gel. Also the solution was added after setting of gel hence evaluating the $\mathrm{pH}$ of the gel may destroy the integrity of the gel.

The grown crystals were collected after 25 days. The particles present in the extract may adhere to the crystal surface and do not bind with magnesium, ammonium or phosphate. It was observed that nucleation was controlled and less number of struvite crystals were formed in comparison with the crystals formed in the control system. Thus an inhibiting effect was observed due to the addition of phyllanthus emblica extract.

To further investigate the inhibiting effect, the water soluble particles of phyllanthus emblica at $5 \% \mathrm{~W} / \mathrm{V}$ concentration was separately added to the supernatant solution in the test tubes right from the beginning of the growth of the crystals and compared with the growth of the struvite crystals in the control system (without phyllanthus emblica extract or its water soluble particles). The prepared phyllanthus emblica extract was precipitated using acetone. This precipitate was separated from the solution and warmed for $5 \mathrm{~min}$ to remove acetone if any present in the precipitate. This precipitate was added along with $10 \mathrm{ml}$ of supernatant solution (magnesium acetate) of $1.0 \mathrm{M}$ concentration and this combination was added gently over the set gels in the test tubes. The experiment was carried out at room temperature. The studies were carried out in seven crystallisation vessels for both control system and the phyllanthus emblica extract added system. The experiments were repeated thrice to ensure the repeatability.

\section{Characterization}

The crystals grown in the control system and water soluble particles of emblica extract at $5 \% \mathrm{~W} / \mathrm{V}$ added system were subjected to various characterization techniques such as powder XRD, FTIR, UV-vis, Microhardness, SEM and Thermal analysis. Powder XRD analysis was carried out using XPERT-PRO diffractometer system using $\mathrm{Cu} \mathrm{K} \alpha$ radiation of wavelength $1.5406 \mathrm{~A}^{\circ}$. The data were analyzed using the related computer software. The sample was scanned in the range of $10^{\circ}$ to $80^{\circ}$ at a scan rate of $2 \% \mathrm{~min}$. The FTIR spectra was recorded at room temperature by means of Bruker, AphaT, instrument using $\mathrm{KBr}$ pellet technique in the wavenumber range $4000-550 \mathrm{~cm}^{-1}$. The UV-vis analysis was carried 


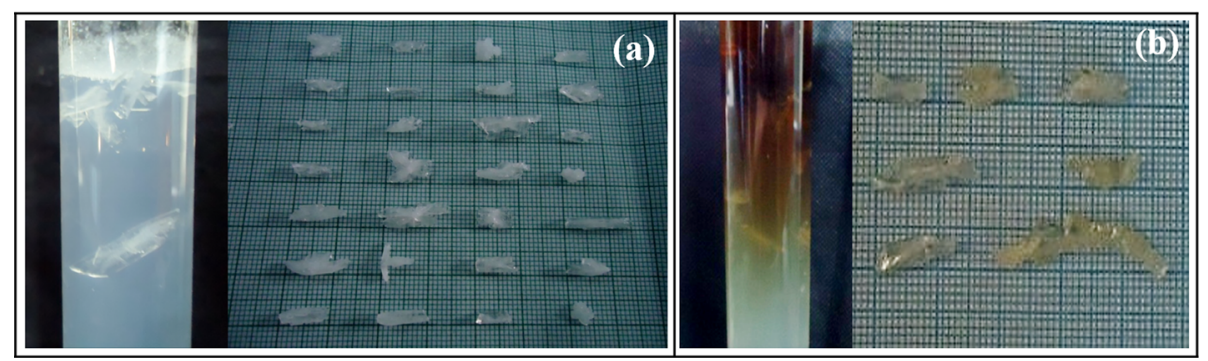

Fig. 1 Struvite crystals grown in the (a) control system (b) emblica extract added system

out using double beam UV-vis spectrophotometer in the range of $200-800 \mathrm{~nm}$. Microhardness studies were carried out using a Vicker's hardness tester (Leitz Wetzlar) fitted with a Vicker's diamond pyramidal indenter and attached to an incident light microscope to understand the mechanical properties of the grown crystals. The microstructures of the grown crystal samples were observed using a scanning electron microscope (Tescan Vega 3). The thermal behaviour of the grown samples were measured from ambient to $700{ }^{\circ} \mathrm{C}$ at a constant heating rate of $10{ }^{\circ} \mathrm{C} / \mathrm{min}$ in the nitrogen atmosphere.

\section{Results and discussion}

The growth of struvite crystals in the control system, phyllanthus emblica extract added system and water soluble particles of phyllanthus emblica at $5 \% \mathrm{M} / \mathrm{V}$ concentration added system were observed at all stages of the growth. The grown struvite crystals in all the systems had dendritic morphology. However the number of struvite crystals formed in the control systems were found to be more than that of the emblica extract added systems. Figure 1 shows the crystals grown in the control system and emblica extract at $5 \% \mathrm{M} / \mathrm{V}$ concentration added system respectively. It was observed that nucleation of struvite crystals was controlled and only a few numbers of crystals was obtained in the phyllanthus emblica extract added system. The average number of crystals grown per vessel in the control system was found to be $28 \pm 3.9$ and the total weight was estimated to be $1.6 \pm 0.3 \mathrm{~g}$, whereas the average number of crystals grown in the emblica extract added system was found to be $11 \pm 2.3$ and the total weight per vessel was estimated to be $1.4 \pm 0.2 \mathrm{~g}$. The difference between control and emblica extract was statistically significant $(\mathrm{p}<0.05)$. This clearly indicates that the phyllanthus emblica reduces the nucleation of struvite crystals and hence has an inhibiting effect on struvite crystal formation. Also, the average size of crystals in the control system was $0.8 \pm 0.2 \mathrm{~cm}$ and that of the extract added crystals per vessel was found to be $1.5 \pm 0.2 \mathrm{~cm}(\mathrm{p}<0.05)$. Figure $2(\mathrm{a})$, (b) shows the variation in the total number of crystals, its average size and total weight in each vessel for the control system and emblica extract added system respectively. Figure 3 illustrates the variation in average no. of crystals, its avg. size and weight for control system and emblica added system. There is about $60 \%$ reduction in the total number of crystal per vessel in the emblica added system. This clearly indicates a significant inhibitory effect of phyllanthus emblica on struvite crystal formation.

\section{Powder XRD analysis}

Whitaker and Jeffery [18] were the first to report the crystal structure of struvite using single crystal XRD data. The powder XRD pattern (Fig. 4) of struvite

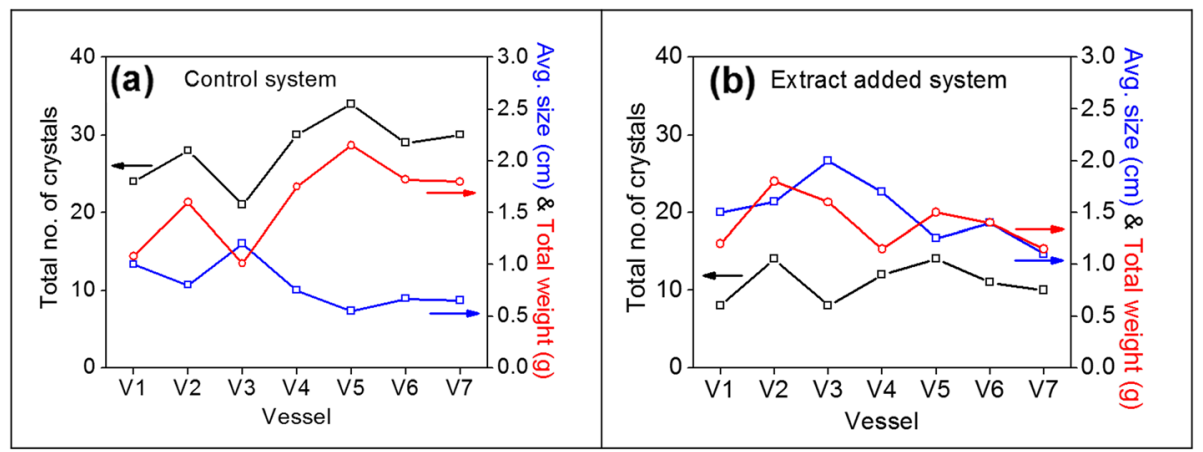

Fig. 2 Variation in the total number of crystals, average size of the crystals and total weight of the crystals in each vessel: (a) Control system (b) Emblica extract added system 


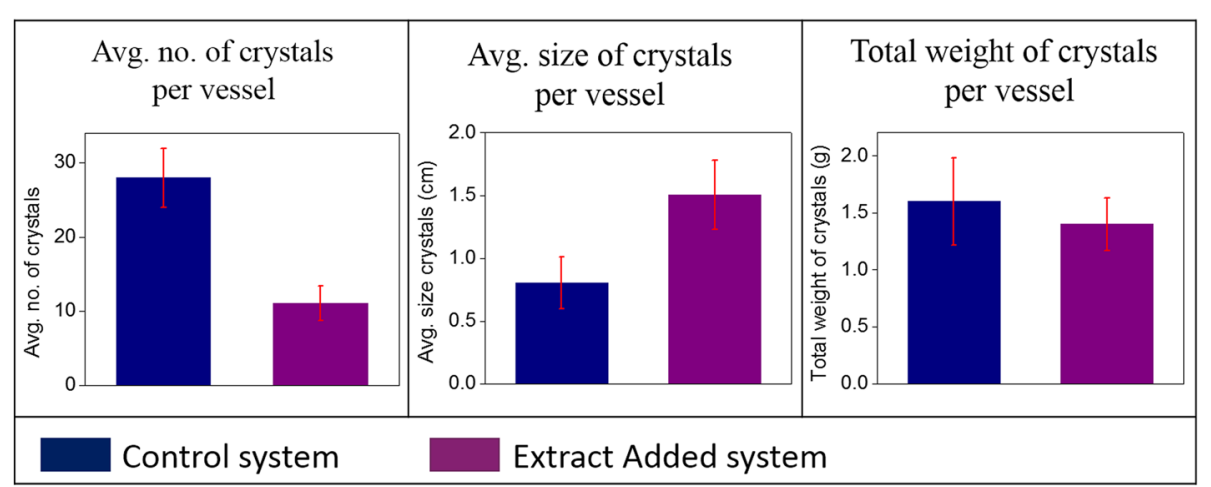

Fig. 3 Comparison of average number of grown crystals, its average size and weight for control system and emblica added system

crystals grown in the gel medium of the control system is identical with the published one [19]. It was found that the grown struvite crystallizes in the orthorhombic system with space group Pmn21 and unit cell parameters $\mathrm{a}=6.908 \mathrm{~A}^{\mathrm{o}}, \mathrm{b}=5.9205 \mathrm{~A}^{\mathrm{o}}, \mathrm{c}=10.6572 \mathrm{~A}^{\mathrm{o}}$. These values agree with those reported by Chauhan and Joshi [20]. There is no major shift in the peak values from those of the emblica extract added system. This implies that there is no significant lattice distortion due to the addition of phyllanthus emblica extract. The well defined peaks at specific $2 \theta$ shows good crystallinity of the grown sample.

\section{FTIR spectral analysis}

Figure 5 shows the FTIR spectra for pure struvite crystal. There is no marked difference between the spectra for pure and extract added struvite crystals and closely resembles the one published [21]. Hence, the grown crystals are characterized as struvite crystals.

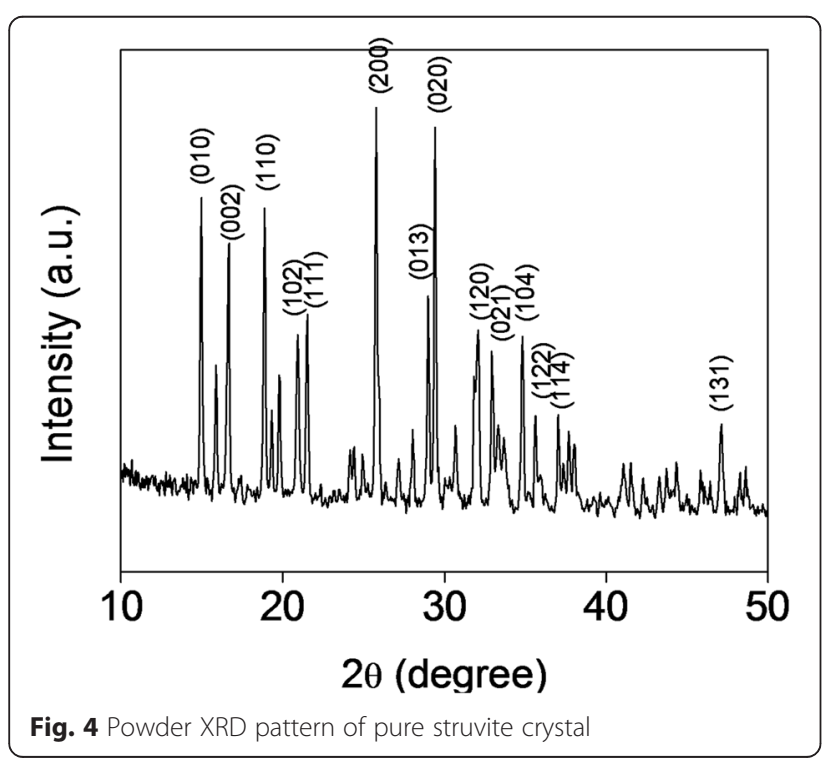

\section{UV- Visible analysis}

The UV-vis spectrum of pure struvite is shown in Fig. 6. It was found that there is no significant absorption in the entire spectrum of study for both the pure and extract added struvite, which means that the grown crystals were transparent in the entire spectral range between $200 \mathrm{~nm}$ and $800 \mathrm{~nm}$ respectively. The band gap for the struvite crystals grown in the control system was found to be $5.07 \mathrm{eV}$. For the phyllanthus emblica extract added struvite crystals, the bandgap energy decreases.

\section{Vickers Microhardness studies}

The hardness of a crystal is a measure of resistance of deformations or movement of dislocations, usually by indentation. It determines the mechanical property of the material. This property is associated with the arrangement of atoms in the lattice and their packing. Transparent crystals grown in the control system and phyllanthus emblica extract added system which are free from cracks and having smooth surface were choosen for the microhardness measurement. The (001) plane of the crystals were identified and indentations were made on these faces at room temperature with the load varying from $25 \mathrm{~g}$ to $100 \mathrm{~g}$ using a Vicker's hardness tester fitted with a Vicker's diamond pyramidal indenter and attached to an incident light microscope. Applying load with a penetrator results in an indent or permanent deformation of the crystal. The indentation time was kept as $5 \mathrm{~s}$ for all the loads. For each load, several indentations were made and the average value of the diagonal length was used to calculate the microhardness. The Vicker's hardness number was calculated using the relation,

$$
H v=1.8544\left(\frac{P}{d^{2}}\right) \mathrm{kg} / \mathrm{mm}^{2}
$$

where, $\mathrm{P}$ is the applied load $(\mathrm{kg}), \mathrm{d}$ is the average diagonal length of the Vicker's impression in $\mathrm{mm}$ after 


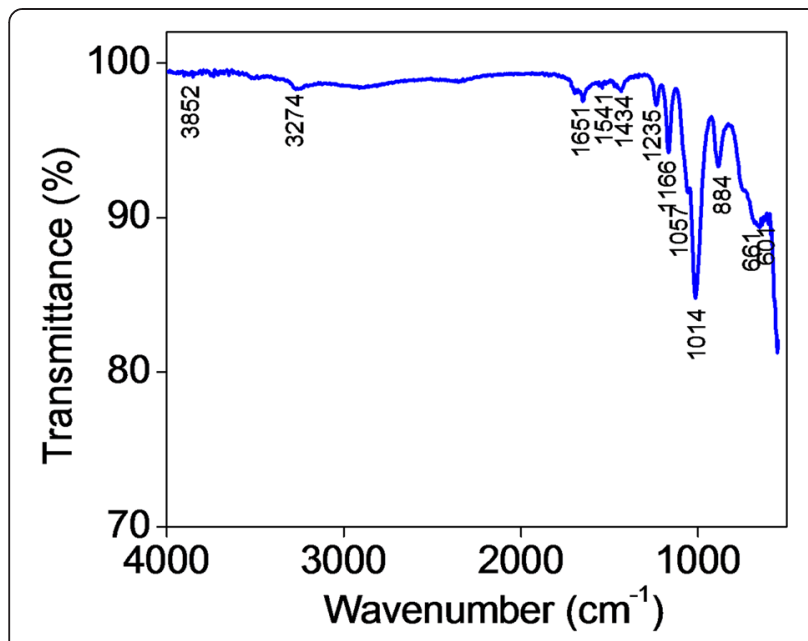

Fig. 5 FTIR spectrum of pure struvite crystal

unloading.1.8544 is a constant of a geometrical factor for the diamond pyramid.

Variations of hardness with load for the pure and phyllanthus emblica extract added struvite crystals are shown in Fig. 7. From the figure it is understood that $\mathrm{H}_{\mathrm{v}}$ increases with load for both the struvite crystals grown in the control system and phyllanthus emblica extract added system.

The nature of the material can be analyzed using Meyer's relation, which is an empirical relation between load $\mathrm{P}$ and indentation diameter $\mathrm{d}$ [22],

$$
\begin{gathered}
P=k d^{n} \\
\log P=\log K+n \log d
\end{gathered}
$$

where $\mathrm{k}$ is an arbitrary constant and $\mathrm{n}$ is the Meyer's index, also known as work hardening coefficient.

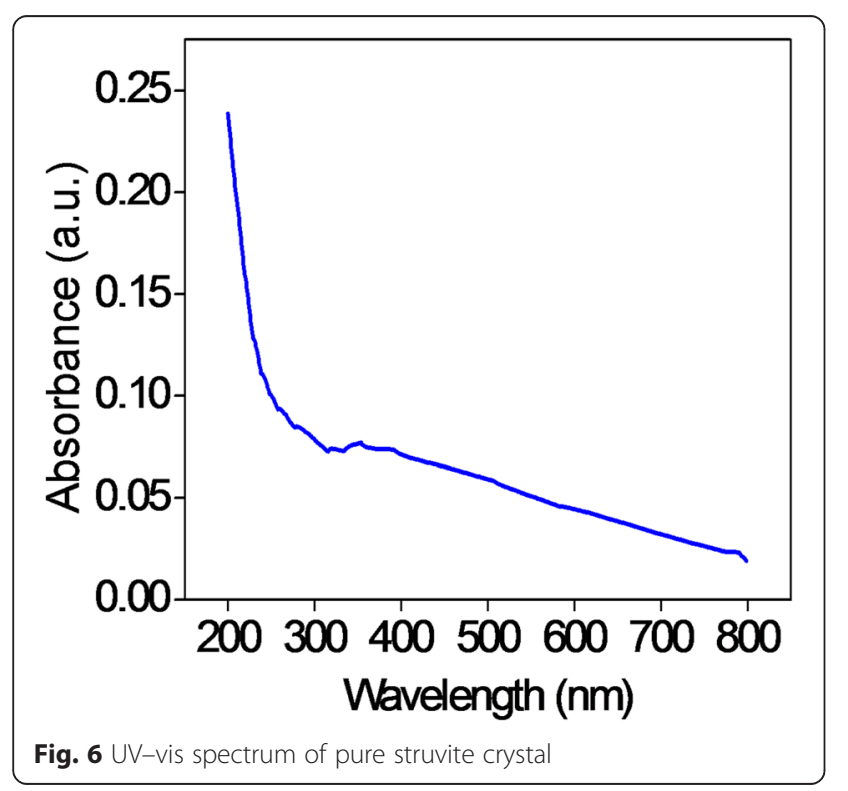

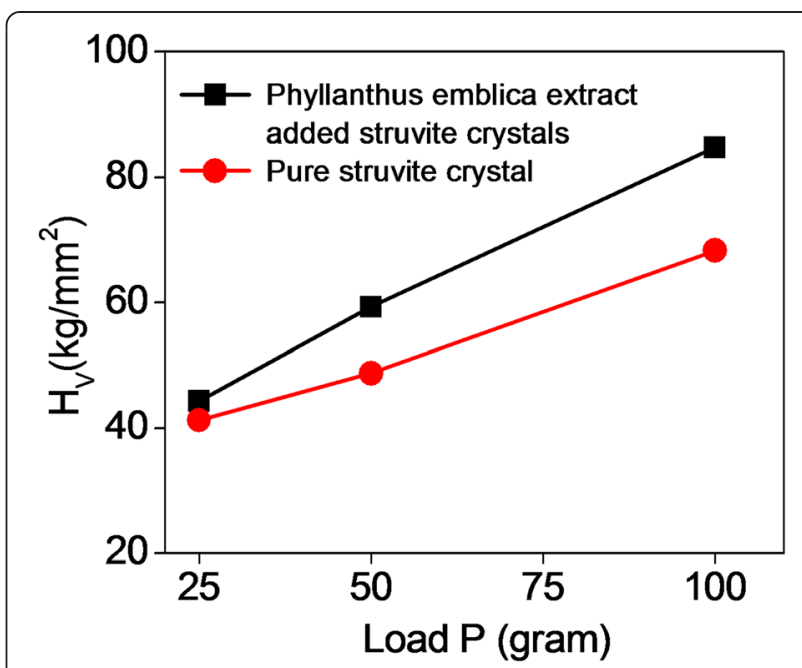

Fig. 7 Hardness vs Load variation curve for pure struvite crystals and phyllanthus emblica extract added struvite crystals

The above relation indicates that $\mathrm{H}_{\mathrm{v}}$ should increase with $\mathrm{P}$, for $\mathrm{n}>2$ and decrease with $\mathrm{P}$, for $\mathrm{n}<2$. To evaluate the value of $n$, a graph is plotted for $\log P$ vs $\log d$ as shown in Fig. 8. The plot gives a straight line after least square fitting, from which the slope provides the work hardnening coefficient ' $n$ '. The work hardening coefficient is estimated to be 3.118 for the pure struvite crystal and 3.78 for phyllanthus emblica extract added struvite crystal respectively. This result for pure struvite agrees with that reported by Suguna et al. [23]. If the work hardening coefficient (n) lies between 1 and 1.6, then the material is a hard material and if $n>1.6$, the material is a soft material. Thus it is found that the crystallized struvite is a soft material. The addition of phyllanthus emblica extract has further softened the struvite crystal.

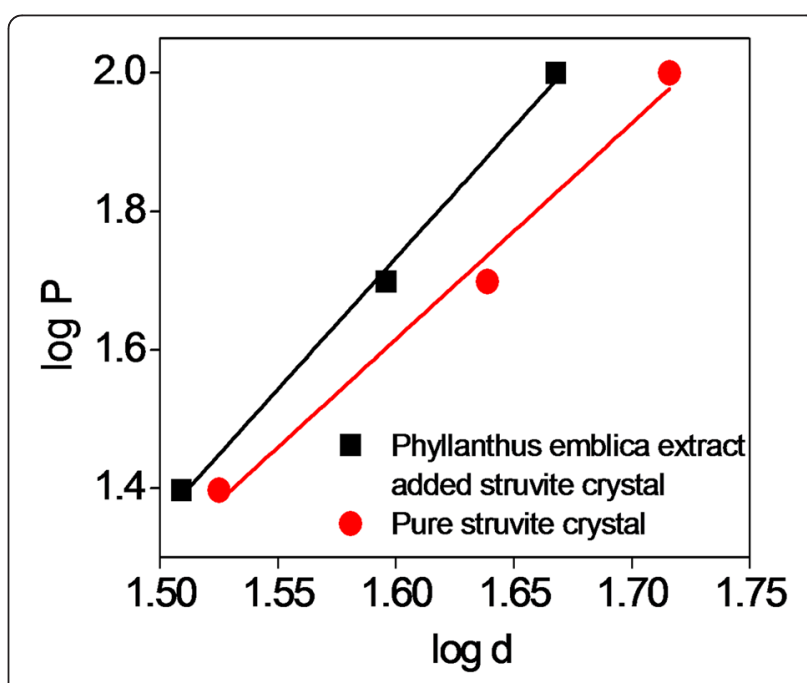

Fig. 8 log P vs log d curve for pure struvite and phyllanthus emblica extract added struvite 

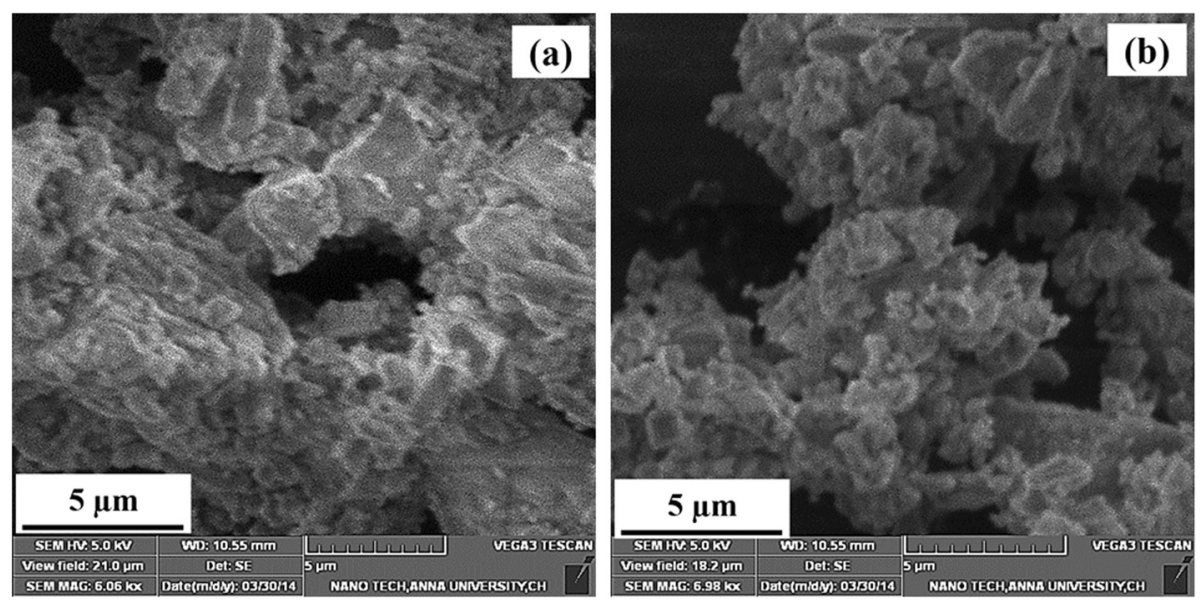

Fig. 9 SEM images of (a) Pure struvite sample (b) Phyllanthus emblica extract added sample

\section{SEM analysis}

Figure 9 shows the SEM images for the pure struvite sample and for sample grown in the presence of phyllanthus emblica extract. The SEM images struvite samples grown in the control system and extract added system showed multi-layered depositions.

\section{Thermogravimetric analysis}

Thermogravimetric analysis is an instrumental technique used to show the variation of mass of the sample when the temperature or time changes. Figure 10 shows the thermal behavior of the struvite samples grown in the control system and phyllanthus emblica extract added system measured from ambient to $700{ }^{\circ} \mathrm{C}$ at a constant heating rate of $10{ }^{\circ} \mathrm{C} / \mathrm{min}$ in the nitrogen atmosphere.

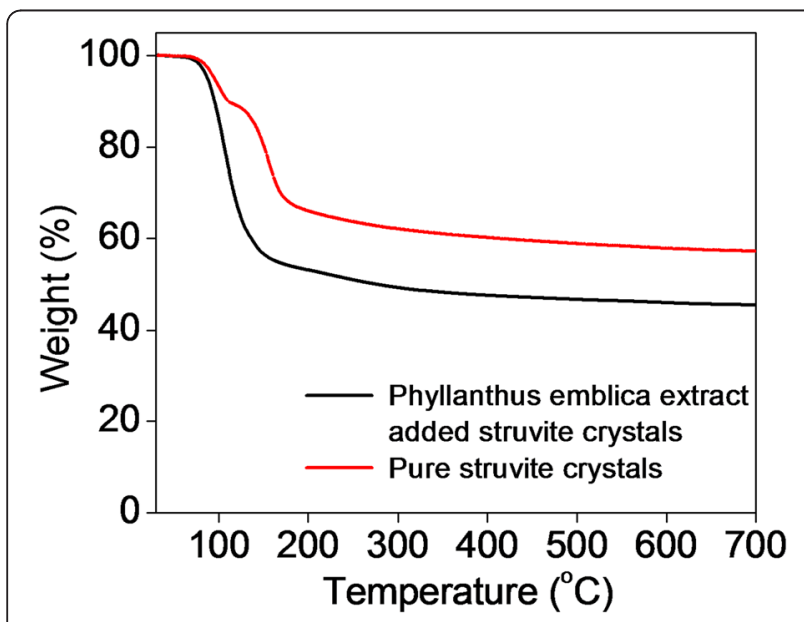

Fig. 10 Thermal behavior of struvite crystals grown in the control system and phyllanthus emblica extract added system
For pure struvite crystal, two stages of weight loss occurred. In the first stage weight loss of $9 \%$ occurs between $77^{\circ} \mathrm{C}$ and $108{ }^{\circ} \mathrm{C}$ and is due to the liberation of water molecule and in the second stage weight loss of $21 \%$ occurs between $127{ }^{\circ} \mathrm{C}$ and $178{ }^{\circ} \mathrm{C}$ and is due to the elimination of nitrogen molecule from the sample. In the case of phyllanthus emblica extract added sample, the weight loss of $43 \%$ occurs between $75{ }^{\circ} \mathrm{C}$ and $155^{\circ} \mathrm{C}$. Hence it is observed that the thermal stability decreases for the struvite crystals grown in the presence of phyllanthus emblica extract.

\section{Conclusions}

The invitro crystallization of struvite crystals were carried out successfully using the gel technique. The role of phyllanthus emblica extract on the struvite crystal formation was investigated and it was found to have an inhibiting effect on the growth of struvite. The grown crystals had dendritic morphology. The number of crystals obtained in the phyllanthus emblica extract added system was found to be less than the control system. Hence, phyllanthus emblica reduces nucleation of struvite crystals and thus act as an inhibitor for struvite crystal formation.

The grown crystals were confirmed by powder XRD and FTIR analysis. The UV-vis analysis showed that the energy gap decreases for the phyllanthus emblica extract added struvite crystals. The microhardness studies further confirmed that the addition of phyllanthus emblica softens the struvite crystals. The SEM images showed that the grown crystals had multilayered depositions. The TGA-DTA analysis confirmed that the thermal stability decreases for the struvite crystals grown in the presence of phyllanthus emblica extract. 


\section{Competing interests}

$\mathrm{BB}, \mathrm{ASS}$ and KVA declare that they have no competing interests.

\section{Authors' contributions}

BB carried out the interpretation of data and drafted the manuscript, ASS contributed to preparation of extract and sample, KVA participated in the modification of the experimental work as well in the interpretation of results. All authors read and approved the final manuscript.

\section{Acknowledgements}

The authors are thankful to St. Josephs College, Trichy for timely characterization of the samples.

\section{Author details}

${ }^{1}$ Department of Physics, Noorul Islam Centre for Higher Education, Kumaracoil, Tamil Nadu 629180, India. ${ }^{2}$ School of Advanced Sciences, VIT University, Vellore, Tamil Nadu 632014, India.

Received: 26 November 2014 Accepted: 4 May 2015

Published online: 08 August 2015

\section{References}

1. Wierzbicki A, Sallis JD, Stevens ED, Smith M, Sikes CS. Crystal growth and molecular modeling studies of inhibition of struvite by phosphocitrate. Calcif Tissue Int. 1997:61:216-22

2. Steven J. Scheinman. Urinary Calculi Med. 2003;31:77-80.

3. Chauhan CK, Joshi MJ, Vaidya ADB. Growth Inhibition of Struvite Crystals in the Presence of Herbal Extract Boerhaavia diffusa Linn. Am J Infect Dis. 2009:5:170-9.

4. Priestly JT, Dunn JH. Branched renal calculi. J Urol. 1949;61:194-203.

5. Griffith DP. Stuvite stone. Kidney. 1978;55:372-82.

6. Bichler KH, Eipper E, Naber K, Braun V, Zimmermann R, Lahme S. Urinary Infection Stone. Int J Antimicrob Agents. 2002;19:488-98.

7. [7]. Senthy Sellaturay. Physical-Chemical basis for struvite stone formation. 2011.http://discovery.ucl.ac.uk/1336882/1/1336882.pdf. Accessed on 14th november 2014

8. Segura JW. Staghorn calculi. UrolClin North Am. 1997;24:71-80.

9. Worcester E, Parks JH, Josephson MA, Thisted RA, Coe FL. Causes and consequences of kidney loss in patients with nephrolithiasis. Kidney Int. 2003;64:2204-13.

10. Chauhan CK, Joshi MJ. Growth inhibition of struvite crystals in the presence of juice of citrus medical inn. Urol Res. 2008;36:265-73.

11. Shashi A, Sanjay Kumar J, Amita V, Mayank K, Monika S. Pathophysiology of kidney, gallbladder and urinary stones treatment with herbal and allopathic medicine: A review. Asian Pac J Trop Dis. 2013;3:496-504.

12. Joshi VS, Parekh BB, Joshi MJ, Vaidya ADB. Inhibition of growth of urinary CHPD crystals with aqueous extracts of Tribulus terrestris and Bergania ligulata. Urol Res. 2005;33:80-6.

13. Natarajan S, Ramachandran E, Blisin SD. Growth of some urinary crystals and studies on inhibitors and promoters. II. X-ray studies and inhibitory or promotery role of some substances. Cryst Res Technol. 1997;32:553-9.

14. Joshi VS, Joshi MJ. The influence of Inhibition of Citric Acid and lemon Juice to the growth of Calcium Hydrogen Phosphate Dihydrate Urinary Crystals. Ind J Pure Appl Phys. 2003:41:183-92.

15. Joseph KC, Parekh BB, Joshi MJ. Inhibition of growth of urinary type calcium hydrogen phosphate dihydrate crystals by tartaric acid and tamarind. Curr Sci. 2005;88:1232-8.

16. Bhandari PR, Mohammad Ameeruddin K. Emblica officinalis (Amla): A review of potential therapeutic applications. International Journal of Green Pharmacy. 2012;6:257-69.

17. Mustapha AA. Medicinal plants with possible anti- HIV activities: A Review. Int J Med Plants. 2014;106:439-53.

18. Whitaker A, Jeffery JW. The crystal structure of struvite. Acta Crystallogr. 1970;B26:1429-40.

19. Chauhan CK, Joseph KC, Parekh BB, Joshi MJ. Growth and characterization of Struvite crystals. Ind J Pure Appl Phys. 2008;46:507-12.

20. Chauhan CK, Joshi MJ, Vaidya ADB. Growth Inhibition of Struvite Crystals by Rotula Aquatica. Ind J Biochem Biophys. 2011;48:202-7.
21. Bindhu $B, A$ sai $\Pi$. Influence of drugs on the formation of struvite urinary calculi. Int J Sci Res Pub. 2012:2:1-4

22. Shetty MN. Dislocations and mechanical behaviour of materials. Delhi: PHI Learning private limited; 2013. p. 6.

23. Suguna K, Thenmozhi M, Sekar C. Growth, spectral, structural and mechanical properties of struvite crystal grown in presence of sodium fluoride. Bull Mater Sci. 2012;35:701-6.

\section{Submit your manuscript to a SpringerOpen ${ }^{\odot}$ journal and benefit from:}

- Convenient online submission

- Rigorous peer review

- Immediate publication on acceptance

- Open access: articles freely available online

- High visibility within the field

- Retaining the copyright to your article

Submit your next manuscript at $>$ springeropen.com 